2. Алексеев Г.А. Влияние тренировочных нагрузок разной направленности на изменение показателей специальной работоспособности бегунов на средние дистанции - М., 2003.- 124 с.

3. Воробьев А.Н. Закономерность в современном тренировочном процессе Теория и практика физ. культуры. - 1986. - С. 29-31.c.

4. Лалаков Г.С. Определение допустимых тренировочных нагрузок, направленных на обучение и совершенствование техникотактического мастерства юных футболистов 10-12 лет /Г.С. Лалаков // Научные труды: Ежегодник, СибГАФК. - Омск,1998. - С. 45-52.

5. Лексаков А.В. Планирование силовой подготовки в структуре нагрузок подготовительного периода у футболистов групп спортивного совершенствования: Автореф. дис. ... канд. пед. наук /А.В. Лексаков. - М., 1998. - 28 с.
6. Матвеев Л.П. Основы спортивной тренировки: Учебное пособие для студентов институтов физической культуры. - М.: Физкультура и спорт, 1977. - 280 с.

7. Платонов В.Н. Общая теория подготовки спортсменов в олимпийском спорте. - К.: Олимпийская литература, 1997. - 583 с.

8. Платонов В.Н., Булатова М.М. Силовая подготовка спортсмена: учебно-методическое пособие часть 1.- Киев.: КГИФК, 1992.- 52с.

9. Сахновский К.П. Подготовка спортивного резерва. - К.: Здоровья, 1990. - 152 с.

10. Юшкевич Т.П. Научно-методические основы системы многолетней тренировки в скоростно-силовых видах спорта циклического характера: - М., 1991. - 311 с.

\title{
THE IMPORTANCE OF LINGUISTIC COMPETENCE IN TEACHING PROCESS
}

\author{
DOI: $\underline{\text { 10.31618/ESU.2413-9335.2020.8.74.787 }}$ \\ Aychurek Muminova \\ Candidate for a Master's degree \\ at Namangan State University
}

\begin{abstract}
Foreign language teachers know that Chomsky's theory about linguistic competence is essential in teaching process. This is why I studied this theory deeply. In this article you can find information about linguistic competence and its usefulness in teaching foreign language.
\end{abstract}

Key words: linguistic competence, linguistic, grammar, kill, psychology, ability, experience.

Chomsky introduced the notion of linguistic competence to explain exactly of what the grammar is a theory. This notion of linguistic competence is an important contribution to understanding language and linguistics. But it has been less well received by philosophers than it should have been, in part because of certain false things Chomsky said about it. In particular, he said that the grammar of a language, considered as a theory of competence, is an idealization, and that speakers know the rules of the correct grammar of their language.Central to Chomsky's work was the idea that the grammar of a language should say exactly what the sentence of the language are and describe the linguistic properties of each of these sentences.

There are infinitely many sentences in any natural language. There is no longest sentence, since all speakers know many ways of extending any sentence to make a longer sentence. So the grammar cannot say what the sentences are by listening them. It is very natural to think that the grammar should be a system of rules that produces or generates the infinitely many sentences of the language together with a linguistic description of each. This is the most obvious way of describing all of the items in an infinite collection.

Once this point of view - that the grammar should generate in a precise way all and only the sentence of the language-is adopted, it is actually a rather short step to the idea that a generative grammar of a natural language must contain rules of a rather special and unusual sort, called transformational rules. Thus, the grammar of a natural language is a transformational generative grammar.

Chomsky combined this with two philosophical views about linguistics. First, he saw linguistics as part of cognitive psychology. Linguistics aims at telling us something about the minds of language users. Knowing a language is, after all, fundamentally a mental matter. And the ability to learn language is a mental ability.

Second, Chomsky wanted to be a scientific realist about linguistic theory. Linguistic theory aims at describing something that exists in nature and is correct only insofar as there is a mental or psychological reality corresponding to it.

The notion of 'competence' has its basic outside linguistics. It plays an important role both in professional life and in disciplines concerned with the professional personality such as sociology, pedagogy, psychology, personal management. Competence is a bundle of cognitively controlled abilities or skills in some particular domain. It implies both knowledge and the ability and disposition to solve problems in that domain. Relevant domains are often occupational areas; and a set of problems in such a domain is often called, for short, a job. The solution of problems presupposes the ability to make informed and responsible choices. Competence is essentially acquired through practice and experience. It is assessed according to some establishing standard.

In psychology, a distinction is made between personal and professional competencies. Since we are concerned with linguistic competence, we may say that from a general point of view, a person's linguistic 
competence is, first and foremost, part of his personality. On the other hand, it is certainly one of those personal competencies that are highly relevant to professional life. As a consequence, linguistic competence is one of the central concepts in applied linguistics, and there it has always been construed in such a way as to be applicable to professional life.

It is aim of the present work to assemble the multifarious aspects of linguistic competence into a comprehensive notion. Many of the empirical issues of the paper have been addressed by applied linguistics, especially by that branch which is devoted to foreign language teaching and learning. There is, however, to this date no unified theory that would be equally applicable to competence in native and foreign languages, to monolingual and plurilingual competence. We need answers to questions such as the following:

- What does speech community consider linguistic competence?

- As for the concept of component speaker formed by different speech communities: where do they differ, so they differ, so that the concept of linguistic competence is culture-bond;

- Can the notion of linguistic competence relevant in a society be operationalized in the form of a test by which the competence of a person in some language can be assessed.

- How do the various factors making up linguistic competence correlate? For instance, does lexical competence correlate with grammatical competence?

- Can a correlation between competence in one's native language and aptitude in foreign languages be ascertained empirically?

- Is there a unified concept of language aptitude in the sense that a person apt for languages is apt both for his native and for foreign languages.

- For of all, answers to such questions have an intrinsic scientific interest. Quite in general, if the notion of competence in a language can be turned into a empirical concept, then a number of issues become empirical issues (Lehman 2015).

When it comes to linguistic competences Chomsky's theory is important because linguistic competences include all concepts according to language learning and teaching. Accepting all these theories teacher create exercises for students.

\section{References}

1.Lehman, Ch. 2007. Linguistic competence: theory and empiry.

2.Tienson, J. 1983. Linguistic competence. University of Nibraska.

3.Chomsky, N. 1957. Syntactic structures. The Hagua, Mouton and Company.

4.Chomsky, N. 1965. Aspects of the theory of syntax. Cambridge, Massachusetts.

5.Chomsky, N. 1966. Topics in the theory of generative grammar. The Hagua, Mouton and Company.

\section{ОСОБЕННОСТИ ОБУЧЕНИЯ ПРОФЕССИОНАЛЬНО-ОРИЕНТИРОВАННОЙ ЛЕКСИКЕ В МАГИСТРАТУРЕ}

\author{
Петухова Галина Николаевна \\ cm. преподаватель кафедры английского языка \\ ГГУ им. Ф. Скоринь \\ Беларусь, г. Гомель
}

Курс обучения английскому языку предусматривает обучение различным видам чтения и извлечением необходимой информации из текста. Ученые разрабатывают различные теории и формы работы с текстом, а значит и с профессионально-ориентированной лексикой прежде всего. Большое внимание уделяется интенсивному введению лексики на всех этапах обучения. Однако такая деятельность особенно важна для магистрантов, поскольку велика вероятность того факта, что они будут активно пользоваться этой лексикой в своей профессиональной и научной деятельности, участвуя в переговорах, конференциях и симпозиумах.

У преподавателя, работающего на второй ступени высшего образования, есть уникальная возможность предъявить магистрантам многообразие приемов работы с профессиональноориентированной лексикой. Поэтому следует довести до сведения магистрантов, что при изучении лексики нужно обращать внимание не только на фонетические особенности слова или его значения. Магистранты должны уметь определить тип структурной единицы, переводить без словаря производные слова с известными корнями и знать основные правила словообразования. Кроме того важно уметь дифференцировать словосочетания и сложные слова, знать значения наиболее употребительных сокращений, касающихся их профессиональной деятельности. Умение подобрать синонимы и антонимы, использовать в речи фразеологизмы и профессиональный слэнг будет способствовать обогащению словарного запаса и разнообразить устные высказывания.

Поскольку в результате разного рода исторических событий на развитие английского языка оказывали влияние различные другие языки необходимо обратить внимание на то, что и в словарном составе произошли некоторые изменения. Например, появились слова, заимствованные из французского, латинского и греческого языков. Для правильного написания и произношения самых распространенных терминов 